\title{
Girindrasekhar Bose and the History of Psychoanalysis in India
}

\author{
Anup Dhar* \\ (Received 16 May 2018; revised 2 July 2018)
}

\begin{abstract}
The 'entry point' into the history of psychoanalysis in India could be offered by 'Savage Freud', Girindrasekhar Bose (1886-1953) (Sinha, 1954, pp. 62-74; Nandy, 1995, pp. 81-144), who practiced proto-psychiatry in a mental hospital, taught psychology and psychoanalysis in the Calcutta University and wrote (psychoanalytically singed) commentaries on the Bhägvad Gìtā (1948, 1931), the Yoga Sütras (1966), the Purānas $(2001,1934)$ and proposed, A New Theory of Mental Life. Girindrasekhar Bose, already a medical professional, obtained a Master's degree in psychology (1917) and was awarded the first doctorate in psychology at an Indian university in 1921. His PhD thesis was titled 'The Concept of Repression'. In writing a 'history of psychoanalysis in India' this paper encounters two questions: why write a history of psychoanalysis and how does one write a history of psychoanalysis. In the process the paper also distinguishes between a logic of the Indian psyche and an 'Indian' logic of the psyche. There is however no one understanding of India, and 'India' is indeed a multi-stranded perspective - a perspective haunted by numerous inner contradictions.
\end{abstract}

Key words: Aboriginalization, Dharma-sañkaț, Difference, Guilt, Oedipus, Orientalism, Psychoanalysis.

\section{INTRODUCTION}

The 'history of psychoanalysis in India' is informed by two central questions: why write a history of psychoanalysis in India and how does one write the history? With respect to the 'why', the paper argues that one perhaps writes the history of a science to mark difference; i.e. to show how a science (in this case, psychoanalysis) has germinated differently in different time-space curvatures, in different cultures, in different contexts. In other words, history of a science is not an increasing formalization of only one particular strand of knowledge; it is multi-stranded at its origin. With respect to the 'how' the paper argues for a move beyond dates and events to a history of ideas, idioms, paradigms, practices, concepts and language; so as to once again mark the work and play of difference at the origin; so as to show how the history of psychoanalysis in India is not just about the logic of the Indian psyche. In that sense, the paper is on the question of methodology.

\section{1 'Why' write the History of a Science?}

First, why write a history of psychoanalysis in India? Is it to demonstrate to the world that 'oh, we also did/had psychoanalysis!' Or is it to assert: we did/had it before you! There was psychoanalysis in India well before Freud founded psychoanalysis in Germany. The 'before you' argument can take a displaced form; we did psychoanalysis before you; but we did not do it the way you did it; we had the Yoga Sütra. The 'before you' can go through a further displacement and become a difference argument. You did psychoanalysis. We did Yoga. Difference in the nature of praxis can also become epistemological difference: you were driven by the

\footnotetext{
*Professor of Philosophy, School of Liberal Studies, Ambedkar University Delhi, Email: anup@aud.ac.in
} 
Cartesian 'mind-body' divide in psychoanalysis (whether there is such a divide in psychoanalysis is of course to be examined); we were working through the divide in Yoga. You built psychoanalysis out of Greek tragedy. We built it out of a re-reading of the Bhāgvad Gìtā. Guilt was the core of Freudian psychoanalysis. Dharma-sankata, self-doubt was the core of the kind of new theory of mental life we developed.

Who are 'we'; and who is this 'you' is of course a complex question. There is no one 'we'; India is a divided perspective (Spivak, 1994; Kakar and Kakar, 2007). There is also no one 'you'. It is hence not about West and East or North and South. History of science qua psychoanalysis will give us a sense - only a sense - of how partial perspectives (not universals) to the human psyche were developed in different corners of the globe depending on the kind of 'soil' the 'psychoanalytic plant' was growing in, depending on the kind of context, culture, and subject positions that were informing the birth of the science qua art qua psychoanalysis. Is history of science then about marking what French philosopher Jacques Derrida (2002, pp. 75, 95, 161, 247) calls differance? Is it about how a certain science (say, psychoanalysis in or from India or Indian psychoanalysis) deferred the assumptions and findings of a certain other science (say, Freudian psychoanalysis)? How a certain science (say, psychoanalysis in or from India or Indian psychoanalysis) differed with the basic tenets and principles of a certain other science (say, Freudian psychoanalysis)? Is history of science then not just about chronicling the birth and growth of a science? Is it not about an increasing formalization of knowledge? Is it not just about the curvature of time; but about the curvature of space; is it then about delineating the distinctive character of a certain science (say, psychoanalysis in or from India or Indian psychoanalysis) in relation to another science (say, Freudian psychoanalysis) in another space?

\section{2. 'HOW' DOES ONE WRITE THE History of a Science?}

This takes me to the second question. How does one write a history of science qua psychoanalysis in India?

\subsection{The Multiple Histories of Psychoanalysis in India}

Problematic one: the history of psychoanalysis in India is not of one kind or of one character. It spans the birth and genesis of psychoanalysis in largely four cities, Kolkata, Mumbai, Delhi and Bangalore including Patna, Benaras, even Rangoon in 1948 ( Samiksha Vol. 1, No. 1-3); marked in turn, by the character psychoanalysis took in each of the four cities; Kolkata: Freudian, Mumbai: Kleinian (building on the works of the Austrian-British psychoanalyst Melanie Klein [1882-1960] and 'object-relations theory'), Delhi: Winnicottian (building on the works of the British Independent Group of the British Psychoanalytical Society and British pediatrician and psychoanalyst Donald W Winnicott [1896-1971]), and Bangalore: Jungian (building on the works of the Swiss psychiatrist and psychoanalyst Carl Jung [1875-1961]). However, none of the cities are informed by any one school of psychoanalysis. The school of psychoanalysis in Kolkata was in critical dialogue with the basic tenets of Freudian psychoanalysis from the 1920s up to the 1970s (the criticality was paradoxically higher during colonial rule; it diminished after political independence). It also marked its difference with Freudian conceptualizations of the psyche. Bose's New Theory of Mental Life (Vol. 1, 1947) to about Vol. 15 (1963) of Samiksha stand testimony to this conversation and to the difference in psychoanalytic conceptualization the school in Kolkata instituted. The school in Delhi was also informed by the works of German psychoanalyst Erik Erikson (1902-94) and Indian psychoanalyst Sudhir Kakar (b. 1938 ) (Kakar, 1982, 1989, 2011). Which history does one then write? 


\subsection{Girindrasekhar Bose's works}

Problematic two: If The Concept of Repression is Bose's early work of critical reflection on, even dissent, with respect to the extant psychoanalytic corpus of conceptualization in Germany, the Bhāgvad Gìtā (written in Bengali) could be considered one of his late and more mature works. It is also paradigmatic of Bose's attempt at rethinking psychoanalysis at the cusp of traditional texts and modern texts, classical Indian texts and contemporary German texts; as also Indian epics and Greek tragedy. It is also an attempt at reading the Bhägvad Gìtā radically and differently:

\begin{abstract}
My knowledge of Sanskrit is limited. However, even with the limited knowledge, I shall write $m y$ interpretation of the Gita. I shall write it through a certain dependence on the dictionaries, on interpretation of existing interpretations, on perhaps extant bhäsyas (from the Preface of the Bhāgvad Gìtä; translation mine).
\end{abstract}

This is how Girindrasekhar Bose begins his Bhāgvad Gìtā. He admits that he could make mistakes in his reading of the Gittā. He also suggests that there is no end to readings and interpretations of the Gittā. However, according to him, most interpretations are either dogmatic; i.e. the interpreter foregrounds in his or her interpretation the philosophy of the path - the märga - the interpreter is a member of. The Bhaktimārga member foregrounds the perspective of bhakti. The jĩ̄anamārga member foregrounds jñāna. Bose finds such readings sectarian, biased. The 'rationalist' in Bose cannot accrue to such over-tilted or over-biased readings. He wants a neutral, an objective reading; only such readings shall open the path to the search for 'truth'. What did the Git $\bar{a}$ really suggest; one needs to look for that. Such a neutral and an objective reading was attempted according to him by Bankim Chandra Chattopadhyaya. However, Bankim could not complete the task. He worked his way up to the $19^{\text {th }}$ śloka of the fourth chapter. Bose however rereads the entire text of the Gitta ; he re-reads it from the perspective and standpoint of psychology-psychoanalysis. Bose re-reads the Gìtā for an inner psychological-psychoanalytic consistency. This consistency is according to Bose the life force of the Gìtā. Bose, however, doesn't limit himself to either The Concept of Repression (1921) or the Bhāgvad Gìtā (also see Bose's 'Gìt $\bar{a}$ ' published in Pravās $\vec{\imath}$ ). For example, he publishes 'A New Theory of Mental Life' in Samiksha, Vol 2, No 2 in 1948 - a monograph which marks in detail his difference with Freud. He also publishes numerous articles in Samiksha. For example, 'Ambivalence' in Samiksha, Vol 3, No 2 in 1949 - which foregrounds the importance of ambivalence in human psychic constitution, 'The Nature of the Wish' in Samiksha, Vol 5, No 4 in 1951 - which demonstrates the importance of the 'see-saw' of the 'double wish', as also the importance of doubled up wish-affects in the psyche. In 1952, Bose published three articles in Samiksha: 'Analysis of Wish' (Vol. 6 No. 1), 'Pleasure in Wish' (Vol. 6 No. 2), and 'Sex and Anxiety' (Vol. 6 No. 3). Bose's The Yoga Sütras was published by The Indian Psychoanalytic Society in 1966. Bose's Bengali book on dreams Svapna was published by the Bangyia Sahitya Parishad in 1986. The history of psychoanalysis in India will hence have to be an in-depth engagement with each of Bose's texts as also the Freudian counterparts of such texts. The history of psychoanalysis in India would thus be an inscription of how Bose marked difference with respect to Freud's corpus of ideas, idioms, and concepts.

\subsection{The Institutional History of Psychoanalysis in India}

Problematic three: the birth of psychoanalysis in colonial India could be broadly mapped through the following events. The introduction of the study of psychoanalysis in the psychology course at the University of Calcutta in 1917 and a subsequent shift of focus in the teaching of psychology to 
psychoanalytic interpretation and the workings of the unconscious; the formation of the Indian Psychoanalytic Society in 1922 and the publication of the journal of the Society, Samiksha, in 1947; in 1939, the Society opened its own mental health institution, the Lumbini Park Mental Hospital; and in 1959, Citta, a Bengali journal was brought out by the Society. While the Department of Psychology was founded inside the premises of the University in 1915, the Indian Psychoanalytic Society emerged outside the academia in 1922. Girindrasekhar Bose thus occupies both positions: one, inside what French psychoanalyst Jacques Lacan in Seminar XVII calls the 'Discourse of the University' (Lacan, 2007, pp. 41) and the other, in terms of the 'Discourse of the Analyst' (Lacan, 2007, pp. 1126). In other words, the history of psychoanalysis takes two forms: one pedagogic, in classroom contexts; the other can be accessed in terms of clinical work and case histories. Which one would take us closer to a history of psychoanalysis? Or would we need to work through both?

\subsection{History of Science: Fort-da between Wind- screen View and Rearview Mirror}

Problematic four: one also needs to, in the process of recuperation, negotiate between the windscreen view (i.e. the direct vision of the "way ahead' or what is to come) and the rearview mirror (i.e. the reflected vision of "what has been left behind'). Driving in terms of the fort-da (fort-da in German; the two-ness of 'far/there/lost' and 'near/here/found' in English) between the windscreen view and the rearview mirror is an apt metaphor of the methodology that marks the writing of the history of psychoanalysis or for that matter, history of any science. In other words, one needs to negotiate between insights coming from an 'ever emergent present' and a 'vanishing past' as one writes; Bose himself is caught in this double bind of appearance and erasure. One thus needs to write at the cusp of questions coming from the contemporary (experimental psychology, behavi- orism, existentialism in early $20^{\text {th }}$ century) and questions coming from the 'Indian past and the Indian context' (questions pertaining to 'faith healing', non-modern and non-western approaches to mental health, debates around 'Indian Psychology' or Indian insights into the inner world and 'Psychology in/from India').

Problematic five: one needs to be menaced by a somewhat primal doubt, doubt marked by the question: is the history of psychoanalysis in India indeed the history of psychoanalysis. Is it psychoanalysis turned upside down? Or is it the other side of psychoanalysis (Lacan, 2007)? Is it the history of 'a new theory of mental life', a new theory, different from the one offered by Freudian psychoanalysis, a theory marked by insights drawn from what gets reflected in the rearview mirror, namely insights from the Yoga Sütra, the Purānas and the Bhāgvad Gitta. Was it stemming from the realization that we cannot perform conventions laid down according to Hebraic-Hellenic-Christian stories? Is the parricide story the beginning of human history? Does not Freud foreclose possibilities of looking at a different (rather than deviant) language game by relegating matrilineal polytheisms or pagan polymorphisms to the prehistory of humankind (Spivak, 1994, pp. 41-75)?

\subsection{Logic of the Indian Psyche: Indian Logic of the Psyche}

Problematic six: the history of psychoanalysis in India would therefore need to ask: what happens when psychoanalysis and India come close? Does India become the analysand (simply put, what in medicine is patient, is analysand in psychoanalysis)? Does India provide to western psychoanalysis case material about the aboriginal world? Or can India emerge as the analyst in this exchange? Can India give back to the west interpretation about the west? What was the nature of aboriginal psychoanalysis? Was it Indian psychology? In which sense was it Indian? Was it the 'Indian logic' of the psyche? Or was it the logic 
of the 'Indian psyche'? It is possible that taking off from an extant logic of the Indian psyche (exemplified by epic manuscripts like the Mahābhārata as against Greek Tragedy) it offers to the west the Indian logic of the psyche (and not just the logic of the Indian psyche). For example, when one takes Oedipus Rex as the 'text of the psychic' one ends up with a narrative of 'acts committed in the context of non-knowledge/ ignorance' (Oedipus did not know who his parents were), remorse/guilt at what one has done, selfchastisement or sacrifice to atone for one's deeds (Oedipus blinds himself). This guilt-ridden traumata sets off the 'psychic teleology'. Freud tries to make a case for such a psychic teleology in Moses and Monotheism. However, if one takes the Bhägvad Gìtā as the text of the psychic, as Bose does, one gets a different psychic teleology, a teleology sparked off by an affront to a menstruating woman in the blind king's court of justice, now being avenged by the collective of husbands she has; however there is a deferral; one of the five husbands is haunted by a near-primal doubt that could be so characteristic of the conception of dharma (what should I do?) and why not, even the conception of the human (who am I?) as well; the doubt is premised on the question: can I kill? Not ordinary killing. Can I kill my relatives, my brothers, my teacher, my grandfather even if I am here to avenge the trauma inflicted on 'my' woman? The answer was 'yes, you have to' to forestall further harm and auxiliary destruction by a group of marauding men. While the premise is guilt (what have I done? The 'should' and 'should not' being known beforehand) in the Oedipal narrative, the premise is dharma (what should I do? Should I kill? The 'should' and 'should not' needs reflection) in the narrative of the Bhāgvad Gittā; even the call of dharma (the a-dharma woman has been subjected to) requires further reflections on dharma (avenge an originary a-dharma over woman); it is, as if, dharma sparking off further reflections on dharma. While in the Oedipal narrative the psychic teleology is sparked off by 'guilt' a posteriori (guilt after the event), in the Bhāgvad Git $\bar{a}$ the psychic teleology is sparked off by 'reflection' on self and dharma a priori. Does this then offer interesting insights for 'another' or even a 'new theory' of mental life; a theory relevant to both east and the west; this/these new theory/theories could be represented as having been born in the east or as having been borne by scholars residing in the east and texts bathing eastern shores.

We are thus left with two possibilities. It is possible that Bose was re-conceptualizing the given contours of (western) psychoanalysis in the Indian context. In the process, he was giving birth to an ab-Original form of psychoanalysis, a form different from the western Original. It is also possible that Bose was giving birth to an aboriginal form of psychology, where aboriginal psychology was not about an isolated insight or data but about questioning the basic paradigm, architectonics and culture of western psychology; this could possibly grant alternative/aboriginal psychologies the right to integrate within, what they see as the best of modern psychology and to reject the bad; and inaugurate in the process a new theory of mental life.

The history of psychoanalysis would perhaps need to be premised on an examination of both possibilities. One would be to read Bose from the perspective of Freud. The other would be to read Freud from the perspective of Bose. This is, of course, not to clinch the exchange between Bose and Freud in favor of the one or the other, but to see what possibilities emerge out of the table-turning. One would be to see Bose's psycho-logic as a version of Freudian psychoanalysis; one then uses Freudian psychoanalysis as the paradigm or at least, benchmark, for understanding Bose's psycho-logic. Here one wishes to see whether Bose was concurring with the principles of Freudian psychoanalysis. Or whether in his engagement - in his immersion/ submersion in psychoanalysis - he was moving 
far from being Freudian/psychoanalytic in his psycho-logic. He was in the process inaugurating a different psychoanalysis - an ab-Original psychoanalysis. Was then Bose a savage Freud, or a savage Klein, or a savage Lacan or at best/ worst a savage Jung? Or was he in the process inaugurating an altogether different or a radically different psycho-logic - different from psychoanalysis, so different that his version is not a 'version of psychoanalysis'; his version is not a version at all; it is original; it is aboriginal in the true sense of the term.

\section{Aboriginalization}

The paper invokes aboriginalization in a two-fold manner. The first is about the now-known history of the 'aboriginalization of certain cultures' during the colonial era. The first is about the characterization of certain cultures as aboriginal and the consequent degradation, devaluing. The first is about Orientalism (both white and brown). The second is about a possible post-Orientalist episteme. The first is about how cultures were made and unmade. The second is about what cultures of knowledge (as against the Orientalist knowledge of cultures) can be produced. The second is about creating cultures of aboriginalization as against an extant aboriginalization of cultures. This is thus not just to 'render the origin genealogical' (as in Foucault) or to 'put under erasure the Original' (as in Derrida). It is to render the 'western Original' aboriginal. It is not just to make micro-changes in western theories, keeping its architechtonics intact; but to aboriginalize its very archi-texture (Nandy, 2004, pp. 324-328). Through a close reading of the long correspondence (1921-1933) between Sigmund Freud and Girindrasekhar Bose of India one could look at both the 'aboriginalization of non-western cultures' and a possible 'culture of the aboriginalization of western knowledge systems' put in place by Bose (Dhar, 2017, pp. 17-48).
In the process, Bose was giving back Freud another psycho-logic - or an Other psycho-logic (which was also not merely about the psycho-logic of the cultural or colonial Other) - a psycho-logic that could be the ground for 'rethinking mental health' not just in India but even in the West. Bose's psycho-logic is then not a displaced Oriental/ Indian version of the western Universal. It is not what could then be represented as an Indian version of the Universal - or an Indian version of the Western Modern - it is not what 'our modernity' was all about. We were actually giving back to the west an aboriginal insight - an insight that would need to be adopted by the West as well; and this insight was not about who we were; it was not just about the Indian psyche; it was not about the possibility that Indian males don't have the castration complex; it was about questioning the very deployment of the castration complex as a constitutive node/anchor of psychic life. It was not about saying that we are or was different. It was to build on this difference and give to the west and to ourselves a different psychology and by default, a different science.

\section{BibliograPHY}

Bose, G. Concept of Repression. Sri Gauranga Press and Kegan Paul, Trench, Troubner and Co., Calcutta and London, 1921.

Bose, G. Gita, Pravasi, 2.1(1931): 9-16.

Bose, G. Bhāgvad Gītā, Indian Psychoanalytic Society: 14, Parsibagan Lane, Kolkata, 1948.

Bose, G. A New Theory of Mental Life, Samiksha, 2.2 (1948): 108-205.

Bose, G. Ambivalence, Samiksha, 3.2(1949): 54-75.

Bose, G. The Nature of the Wish, Samiksha, 5.4(1951): 203214.

Bose, G. Analysis of Wish, Samiksha, 6.1(1952): 1-11.

Bose, G. Pleasure in Wish, Samiksha, 6.2(1952): 53-69.

Bose, G. Sex and Anxiety, Samiksha, 6.3(1952): 191-200.

Bose, G. The Yoga Sūtras, The Indian Psychoanalytic Society, Calcutta, 1966. 
Bose, G. Svapna, Bangyia Sahitya Parishad, Calcutta, 1980.

Bose, G. and Freud, S. The Beginnings of Psychoanalysis in India: Bose-Freud Correspondence. The Indian Psychoanalytic Society, Calcutta, 1999.

Derrida, J. Writing and Difference, Trans with an Introduction by Alan Bass, Routledge, London and New York, 2002.

Dhar, A. The Other Father: Oedipus, anti-Oedipus and the an-Oedipal, Imperial Maladies: Literatures on Healthcare and Psychoanalysis in India, (Ed.) Debashis Bandyopadhyay and Pritha Kundu, Nova Science Publishers, New York, 2017.

Kakar, S and Kakar, K. The Indians: Portrait of a People, Penguin-Viking, New Delhi, 2007.

Kakar, S. Shamans, Mystics and Doctors. A Psychological Inquiry into India and its Healing Traditions. Oxford University Press, New Delhi, 1982.

Kakar, S. Intimate Relations: Exploring Indian Sexuality, Penguin India, New Delhi, 1989.
Kakar, S. A Book of Memory: Confessions and Reflections, Viking Penguin, New Delhi, 2011.

Lacan, J. The Seminar of Jacques Lacan - The Other Side of Psychoanalysis - Book XVII, (Ed.) Jacques-Alain Miller and trans. with notes by Russell Grigg, W. W. Norton \& Co., New York and London, 2007.

Nandy, A. The savage Freud and other essays on possible and retrievable selves, Oxford University Press, Delhi, 1995.

Nandy, A. Towards an Alternative Politics of Psychology, Bonfire of Creeds: the Essential Ashis Nandy, Oxford University Press, Delhi, 2004.

Sinha, T. A Short Life Sketch of Girindrasekhar Bose, Samiksha, Bose Special No., Ed. Nagendranath Dey, 8.1(1954): 62-74.

Spivak, G C. Psychoanalysis in the left field and field working: Examples to fit the title, Speculations after Freud: Psychoanalysis, Philosophy and Culture, (Ed.) S. Shamdasani and M. Munchow, Routledge, London, 1994. 